\title{
Effectiveness of benthic foraminiferal and coral assemblages as water quality indicators on inshore reefs of the Great Barrier Reef, Australia
}

\author{
S. Uthicke $\cdot$ A. Thompson $\cdot$ B. Schaffelke
}

Received: 12 July 2009/ Accepted: 9 November 2009/Published online: 3 December 2009

(C) The Author(s) 2009. This article is published with open access at Springerlink.com

\begin{abstract}
Although the debate about coral reef decline focuses on global disturbances (e.g., increasing temperatures and acidification), local stressors (nutrient runoff and overfishing) continue to affect reef health and resilience. The effectiveness of foraminiferal and hard-coral assemblages as indicators of changes in water quality was assessed on 27 inshore reefs along the Great Barrier Reef. Environmental variables (i.e., several water quality and sediment parameters) and the composition of both benthic foraminiferal and hard-coral assemblages differed significantly between four regions (Whitsunday, Burdekin, Fitzroy, and the Wet Tropics). Grain size and organic carbon and nitrogen content of sediments, and a composite water column parameter (based on turbidity and concentrations of particulate matter) explained a significant amount of variation in the data (tested by redundancy analyses) in both assemblages. Heterotrophic species of foraminifera were dominant in sediments with high organic content and in localities with low light availability, whereas symbiontbearing mixotrophic species were dominant elsewhere. A similar suite of parameters explained $89 \%$ of the variation in the FORAM index (a Caribbean coral reef health indicator) and $61 \%$ in foraminiferal species richness. Coral richness was not related to environmental setting. Coral
\end{abstract}

Communicated by Environment Editor Prof. Rob van Woesik

Electronic supplementary material The online version of this article (doi:10.1007/s00338-009-0574-9) contains supplementary material, which is available to authorized users.

S. Uthicke $(\bowtie) \cdot$ A. Thompson · B. Schaffelke

Australian Institute of Marine Science, PMB No 3, Townsville, QLD 4810, Australia

e-mail: s.uthicke@aims.gov.au assemblages varied in response to environmental variables, but were strongly shaped by acute disturbances (e.g., cyclones, Acanthaster planci outbreaks, and bleaching), thus different coral assemblages may be found at sites with the same environmental conditions. Disturbances also affect foraminiferal assemblages, but they appeared to recover more rapidly than corals. Foraminiferal assemblages are effective bioindicators of turbidity/light regimes and organic enrichment of sediments on coral reefs.

Keywords Foraminifera - Hard coral - Water quality . Environmental indicator - Sediment quality .

Redundancy analysis

\section{Introduction}

Coral reefs are currently a focus of public and scientific debate because of their vulnerability to global disturbances such as rising sea temperatures and ocean acidification (e.g., Fabricius et al. 2007; Hoegh-Guldberg et al. 2007). In addition to climate change, regional and local anthropogenic impacts such as overfishing and eutrophication continue to affect coral reefs and are likely to interact with global stressors. Scientists and managers have realised that continued management of local disturbances is vital to provide corals and reef organisms with the maximum resilience to cope with global stressors (Bellwood et al. 2004; Marshall and Johnson 2007).

The Great Barrier Reef (GBR) lagoon receives suspended sediments and nutrients from land runoff, which has increased several-fold during the last 150 years (Neil et al. 2002; Furnas 2003; McCulloch et al. 2003); the area now exposed to runoff is about ten times larger than 100 years ago (Wooldridge et al. 2006). Coastal waters adjacent to 
agricultural lands have higher concentrations of dissolved and particulate nutrients, chlorophyll $a$ and suspended sediments, especially during the summer wet season, compared to coastal areas adjacent to undeveloped catchments and offshore areas (e.g., Brodie et al. 2007; Cooper et al. 2007). However, water quality parameters are highly variable in space and time which necessitates frequent measurements to adequately determine true concentration ranges. The measurement of biological indicators has significant advantages over directly measuring water quality to assess the chronic or acute effects of changes in water quality on reef health. Appropriate biological indicators can integrate the effects of acute and chronic disturbances over various time scales (Cooper and Fabricius 2007). The understanding of the consequences of high nutrients and suspended sediments for the health of inshore coral reefs is improving (Fabricius 2005; Done et al. 2007; Lirman and Fong 2007), but inferences often depend on selected indicators.

Based on changes in overall coral cover, Pandolfi et al. (2003) concluded that GBR outer shelf reefs are the most pristine reefs among reefs in 14 global geographical regions, but nonetheless about $30 \%$ are on the way towards 'ecological extinction', followed by the GBR inshore reefs (about 37\%). Coral cover declined drastically on some reefs of the GBR over the last decades, similar to other Indo-Pacific reefs (Bellwood et al. 2004; Bruno and Selig 2007). However, coral cover is affected by various acute disturbances such as mass coral bleaching, tropical storms and outbreaks of the coral-eating crown-of-thorns seastar (Acanthaster planci), which may obscure any, perhaps more subtle, chronic water quality effects (Cooper and Fabricius 2007). Species-specific tolerances are also important; for example, differential tolerance to light attenuation has long been implicated in observed changes in coral community composition along environmental gradients (e.g., Done 1982) but not necessarily in changes in total coral cover. Various other attributes of coral-reef communities, which could be considered indicators, change along water quality gradients of increasing turbidity and availability of nutrients and organic matter towards the GBR coast. For example, macroalgal cover increases, and abundance and richness of many hard-coral and octocoral taxa decrease (van Woesik et al. 1999), maximum depth of reef development decreases (Cooper et al. 2007), and benthic microalgae show physiological adaptations to low light levels (Uthicke 2006). Coral species richness is lower on GBR reefs adjacent to land with intense agriculture (DeVantier et al. 2006), and octocorals shift from phototrophic to heterotrophic assemblages towards the coast (Fabricius and De' ath 2008).

Foraminifera are well established indicators for marine and estuarine pollution in temperate regions (Alve 1995) and have been applied as indicators for coral reef water quality in Florida and the Caribbean using a simple index, the 'FORAM index' (Hallock 2000; Hallock et al. 2003). Shifts in the index (based on grouping foraminifera into three functional groups: symbiotic, opportunistic and 'other small') over time coincided with general reef degradation caused by land runoff (Hallock et al. 2003). The FORAM index corresponded well to a water quality gradient in the GBR, suggesting that decreased light and increased organic matter availability may cause a shift towards higher contribution of heterotrophy (Uthicke and Nobes 2008; Schueth and Frank 2008).

Here, the relationships between environmental variables (i.e., water and sediment properties) to both hard-coral and benthic foraminiferal assemblages were analysed to assess the effectiveness of either assemblage as an indicator of environmental (water and sediment) quality. We used data from a large-scale monitoring programme on inshore reefs of the GBR. Specifically, two hypotheses were tested: (1) the regional and local setting of these reefs result in different environmental conditions (e.g., different concentrations of nutrients and suspended solids in the water column, and different grain size and organic content in reef sediments); and (2) these differences in environmental setting correspond to differences in assemblage composition and diversity for coral and foraminiferal assemblages.

\section{Materials and methods}

\section{Sampling design}

The Reef Plan Marine Monitoring Program is part of a government initiative "to halt and reverse the decline in water quality entering the GBR" (Queensland Government and Commonwealth of Australia 2003) and monitors water quality and coral reef status in the inshore GBR lagoon ( $\sim 30$ reefs along $\sim 1,000 \mathrm{~km}$ of coastline) since 2005 . Monitoring locations were selected to represent reefs along most of the GBR coastline and can be broadly grouped into four geographical regions based on major river catchments. The four regions were the Wet Tropics (10 locations), Burdekin (6 location), Whitsunday (7 location), and Fitzroy (4 locations) regions; thus yielding a total of 27 reef locations (see Table S1 in electronic supplement). All locations are within $30 \mathrm{~km}$ off the coast and have a welldeveloped reef flat, indicating past reef accretion. At each location, sampling was conducted at two sites (separated by at least $200 \mathrm{~m}$ ), each with five permanently marked 20-m transects (separated by $5 \mathrm{~m}$ ) contouring the reef slope at a depth of $5 \mathrm{~m}$ below Lowest Astronomical Tide (LAT). Coral and foraminiferal assemblage data were collected in both 2005 and 2006 (Table S1 identifies locations which were only sampled in one year). 
Hard-coral assemblages

Cover of coral genera was estimated using the point intercept technique. Digital photographs were taken at $50-\mathrm{cm}$ intervals along each $20-\mathrm{m}$ transect. For 32 images, the identity of the benthic organisms beneath five evenly spaced points was recorded. The taxonomic resolution varied; some coral taxa were identified to genus level, while others were identified to species. The genus Acropora was further divided into the growth forms bottlebrush, branching, corymbose, digitate, and tabulate. Porites spp. were scored as branching, submassive/encrusting, or massive growth forms. The proportion of points identified from all five transects yielded cover estimates for each taxon at each site. Cover data were averaged for each location.

\section{Foraminiferal assemblages}

Using a cut-off plastic syringe (diameter $2.8 \mathrm{~cm}$ ), ten cores of the top 1-cm sediment layer were collected haphazardly from deposits along the five coral transects at each site. Four of these samples were pooled for sampling of foraminifera, the remaining six were pooled for the analysis of sediment-quality variables. For the estimation of foraminiferal abundances, sediments were washed with freshwater in a $63 \mu \mathrm{m}$ sieve to remove small particles. After drying $\left(>24 \mathrm{~h}, 60^{\circ} \mathrm{C}\right)$ and mixing, all foraminifera were collected from haphazard subsamples until a minimum of 200 specimens per site were obtained.

Only intact specimens which showed no sign of ageing and little damage were considered. Samples thus defined are a good representation of the present-day biocoenosis (Yordanova and Hohenegger 2002), although not all specimens may have been alive at the time of sampling. Foraminiferal species composition was determined in microfossil slides under a dissection microscope. Most taxa were identified to genus or species level, following Nobes and Uthicke (2008). The dry weight of the sediment and the foraminifera was determined to calculate foraminiferal densities and to estimate the per cent contribution of intact foraminifera to the total sediment. Because the main emphasis of this study was to investigate between location variation, and to allow comparison to environmental parameters, abundance data from the two sites were averaged for each location.

\section{Sediment quality}

Pooled sediment cores from each site were analysed for granulometrics and the proportional composition of organic carbon, total carbon and nitrogen. Grain size fractions were determined by dry sieving larger fractions $(>1.4 \mathrm{~mm})$ and MALVERN laser analysis of smaller fractions $(<1.4 \mathrm{~mm})$. Total carbon (carbonate carbon + organic carbon) and nitrogen were determined by combustion of dried and ground samples, on a LECO Truspec $\mathrm{C} / \mathrm{N}$ Analyser. Organic carbon was measured using a Shimadzu TOC-V Analyser with a SSM-5000A Solid Sample Module after acidification of the sediment with $2 \mathrm{M}$ hydrochloric acid. Inorganic (carbonate) carbon was calculated as the difference between total carbon and organic carbon values.

\section{Water quality}

Water column sampling was carried out during two wet and two dry seasons (August-September 2005, January 2006, August-October 2006 and February-April 2007) in close proximity to each survey reef. Secchi depth (a measure of water transparency, as a proxy for underwater light attenuation) was measured at each sampling location. Discrete water samples were collected from two to three depths through the water column with Niskin bottles. Salinity was measured in subsamples using a Portasal Model 8410A Salinometer. Sub-samples for total dissolved nitrogen and phosphorus (TDN, TDP) and dissolved organic carbon (DOC) were immediately filtered through a $0.45 \mu \mathrm{m}$ filter cartridge (Sartorius MiniSart N) into acidwashed screw-cap plastic test tubes and stored at $-18^{\circ} \mathrm{C}$ until analysis. Samples for DOC were acidified with $100 \mu \mathrm{l}$ of AR-grade $\mathrm{HCl}$ and stored at $4^{\circ} \mathrm{C}$ until analysis. TDN and TDP were analysed after persulphate digestion (Valderrama 1981) by standard wet chemical methods for inorganic nutrients (Parsons et al. 1984) implemented on a segmented flow analyzer (Bran and Luebbe AA3). DOC concentrations were measured by high temperature combustion $\left(680^{\circ} \mathrm{C}\right)$, using a Shimadzu TOC-5000A carbon analyser.

Sub-samples for particulate nutrients and chlorophyll $a$ were collected on pre-combusted glass fibre filters (Whatman $\mathrm{GF} / \mathrm{F}$ ) and stored at $-18^{\circ} \mathrm{C}$ until analyses. Particulate nitrogen (PN) was determined by high temperature combustion using an ANTEK 707/720 Nitrogen Analyser (Furnas et al. 1995). Particulate phosphorus (PP) was determined spectrophotometrically as inorganic $\mathrm{P}\left(\mathrm{PO}_{4}\right.$, Parsons et al. 1984) after digestion in 5\% potassium persulphate (Furnas et al. 1995). Particulate carbon (POC) was analysed by high temperature combustion $\left(950^{\circ} \mathrm{C}\right)$ using a Shimadzu TOC-V carbon analyser with SSM-5000A solid sample module after acidification with concentrated phosphoric acid. Chlorophyll $a$ concentrations were measured fluorometrically using a Turner Designs 10AU fluorometer after grinding the filters in $90 \%$ acetone (Parsons et al. 1984).

Sub-samples for suspended solids (SS) were collected on pre-weighed, $0.4 \mu \mathrm{m}$, polycarbonate filters $(47 \mathrm{~mm}$ diameter, GE Water \& Process Technologies), and SS 
concentrations were determined gravimetrically from the weight difference between loaded and unloaded filters after drying overnight at $60^{\circ} \mathrm{C}$. Sediment samples and water quality data were not collected from Peak Island, thus, statistical analyses comparing assemblage composition to environmental data excluded that location.

\section{Statistical analyses}

Foraminiferal counts and coral cover estimates were converted to relative abundance and cover by dividing estimates for each taxon by the total abundance or cover, respectively. Relative abundance data were fourth root transformed for all statistical analyses. Mantel tests based on Spearman Rank correlations and 10,000 permutations were used to measure relatedness of two similarity matrices (i.e., either foraminiferal or coral assemblage data from two different years, or between foraminiferal and coral data from the same set of locations). Regional differences in assemblage composition for both foraminifera and corals were tested by Analysis of Similarity (ANOSIM), and the taxa contributing most to the dissimilarity between regions were identified by Similarity percentage (SIMPER) analyses. For matrix comparisons and ANOSIM, similarity matrices were calculated using Bray Curtis similarities. Mantel tests, SIMPER, ANOSIM, and diversity calculations ( $S=$ taxa richness) for each location were conducted in Primer (Clarke and Gorley 2001). Richness of coral assemblages was calculated only for genera, not considering the different growth forms.

The influence of sediment and water quality parameters on foraminiferal and coral assemblage composition was investigated with redundancy analysis (RDA). Environmental data were $\mathrm{z}$-transformed $($ mean $=0, \mathrm{SD}=1$ ) prior to analysis to accommodate different measurement units, and data were averaged over sampling seasons and years ( $N=4$ water quality, $N=2$ sediment quality for each reef). Fourth root transformed assemblage data were centred by row means for RDA. Exploratory correlation and principal component analyses indicated that several of the environmental parameters were highly correlated; these were combined before further analysis by averaging their $\mathrm{z}$-scores, as follows. The per cent contribution of small sediments and medium-sized sediments were highly correlated; therefore sediment up to $63 \mu \mathrm{m}$ grain size (clays and silt), those between 63 and $250 \mu \mathrm{m}$ (very fine and fine sands), and those above $250 \mu \mathrm{m}$ were binned. However, the latter group was omitted from statistical analyses, since the three groups were not independent (because their contribution adds up to $100 \%)$. Sediment organic carbon and nitrogen values were also combined to form a "sediment organic matter content" parameter. The water quality parameters related to water clarity (particulate organic carbon, phosphorous and nitrogen; suspended solids, chlorophyll $a$, dissolved organic carbon, Secchi depth) were pooled (Secchi depth with reversed sign) to create a combined "water column particulates" parameter. In addition, hard-coral cover was included as an environmental parameter in the foraminiferal analysis.

For the RDA, the influence of environmental parameters on the foraminiferal and coral assemblages was assessed after removing ('partialling out') the spatial effects of 'Region' which were distinct in both data sets (see "Results"). The amount of variation explained by each of the environmental variables was examined individually, and the significance of the explained variance tested with permutation tests (1,000 permutations). Only environmental variables that were at least marginally significant $(p<0.1)$ were included in the final model. Prior to RDA, a detrended correspondence analysis (DCA) was conducted with transformed assemblage data. Axis lengths for foraminiferal (Axis $1=1.77,2=1.32$ ) and coral data (Axis $1=3.15,2=2.06$ ) were within the range indicative of near monotonic response curves, thus indicating that RDA assumptions were not violated (Jongman et al. 1995).

The same environmental parameters as for the RDA (also z-transformed) were used in a multiple regression analysis to test if they could be used as predictors for the FORAM index or for foraminiferal and coral diversity (expressed as taxa richness). The FORAM index was calculated according to Hallock et al. (2003), by grouping foraminiferal taxa into symbiotic, opportunistic and 'other small' taxa. For each sample, the number of individuals of each of these groups were multiplied with a group-specific weighting factor and divided by the total number of foraminifera (Hallock et al. 2003). The resulting values for each of the three groups were added up to form the FORAM index. All environmental parameters were initially included in the model and those that did not contribute significantly to the respective model were removed from the model by backwards elimination. The latter analyses, RDA, and DCA were conducted in R (R Development Core Team 2006).

\section{Results}

Water and sediment quality

Considerable variation in several biological and environmental parameters was observed between Great Barrier Reef (GBR) inshore reefs (see Tables S1, S2 in the electronic supplement). Coral cover ranged from 5 to $71 \%$. Organic and inorganic carbon and nitrogen content in the sediment varied three to fivefold, and the average grain size varied 33-fold between sampling locations (Electronic 
Supplement Table S1). Most particulate water quality parameters and Secchi depth varied two to eightfold between locations, with the largest range observed in suspended solids concentrations (electronic supplement Table S2). Total dissolved nutrients and dissolved organic carbon varied only one to threefold, with smallest variation observed in salinity.

The first and the second axes of a Principal Component Analyses (PCA) explained $62.5 \%$ of the variation of the water and sediment quality parameters between sampling locations (Fig. 1). The percentage of clay and fine sands and the organic content (carbon and nitrogen pooled) of the sediments were negatively correlated with the inorganic carbon content; these four sediment parameters were the main contributors to the first axis. Water column particulates (the pooled parameter including several components of particulate matter, dissolved organic carbon and Secchi depth) and salinity were negatively correlated with each other and were the main contributors to the second axis. Total dissolved phosphorus and nitrogen contributed less to the first two axes of the PCA. The environmental setting of the sampling reefs in the four 'Regions' largely overlapped, but the Whitsunday Region was different than the other regions and was associated with sediments of small grain size and high organic content.

Foraminiferal assemblages

Benthic foraminifera on the 27 inshore GBR reefs were grouped into 50 taxa. Most of these were identified to species level; however, some of the smaller-sized taxa could only be differentiated to genus level (Table 1). To facilitate later discussion, Table 1 also includes trophic status of the respective taxa, with aposymbiotic taxa presumed to be heterotrophic, and symbiont-bearing taxa mixotrophic. The symbiont type was also listed for the latter group. Total average relative abundance of foraminiferal taxa varied widely between very rare species (total average $<0.1 \%$ ) and common species. The most common taxa, jointly representing about $63 \%$ total relative abundance were Calcarina mayorii (22.4\%), Quinqueloculina spp. (13.2\%), Amphistegina spp. (11.5\%), Calcarina
Fig. 1 Principal Component Analysis (PCA) biplot of the water quality and sediment data (both z-transformed) from sampling locations, pooled over 2 years. Polygons surround reefs in the same region (Wet Tropics Region: circles; Burdekin Region: squares, Whitsunday Region: triangles, Fitzroy Region: diamonds). TDP Total dissolved phosphorus, TDN Total dissolved nitrogen, SedCN pooled sediment organic carbon and nitrogen content, Sed $<63$ : proportion of sediments $<63 \mu$ m grain size, Sed $<250$ : proportion of sediments between 63 and $250 \mu \mathrm{m}$ grain size, Particulates: pooled variable including particulate organic carbon, particulate phosphorous and nitrogen, suspended solids, chlorophyll $a$, dissolved organic carbon and Secchi depth (with reversed sign, thus increasing values of this variable represent high particulate matter and low visibility), Sediment IC: sediment inorganic carbon. See electronic supplement for full names of sample locations

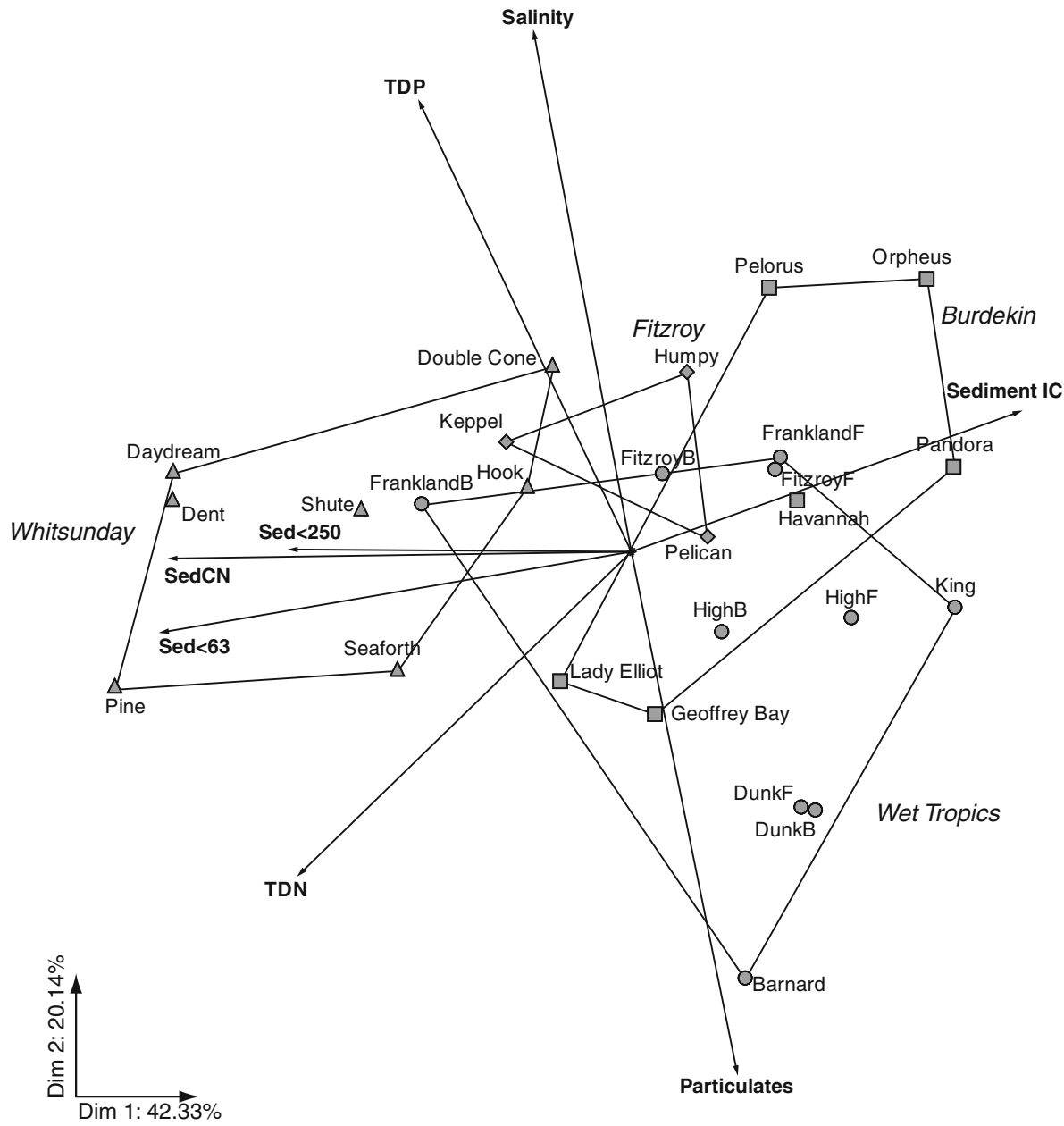


Table 1 Foraminiferal taxa and coral taxa observed

\begin{tabular}{|c|c|c|c|c|c|}
\hline \multicolumn{4}{|c|}{ Foraminifera } & \multicolumn{2}{|l|}{ Corals } \\
\hline Order & Family & Species & Symbionts & Family & Taxon \\
\hline Lagenida & Polymorphinidae & Sigmoidella elegantissima & $N$ & Acroporidae & $\begin{array}{l}\text { Acropora spp. } \\
\text { Astreopora spp. } \\
\text { Isopora spp. } \\
\text { Montipora spp. } \\
\text { Leptoseris yabei }\end{array}$ \\
\hline \multirow[t]{19}{*}{ Miliolida } & Hauerinidae & Pseudohauerina involuta & $N$ & & Pachyseris spp. \\
\hline & Miliolidae & Discorbinella sp. & $N^{*}$ & & Pavona spp. \\
\hline & & Miliolinella sp. & $N$ & Astrocoeniidae & Palauastrea ramosa \\
\hline & & Planispirinella exigua & $N$ & Dendrophylliidae & Turbinaria spp. \\
\hline & & Pseudomassalina sp. & $N$ & Euphyllidae & Euphyllia spp. \\
\hline & & Pyrgo spp. & $N$ & & Physogyra lichtensteini \\
\hline & & Quinqueloculina spp. & $N$ & & Plerogyra spp. \\
\hline & & Triloculina spp. & $N$ & Faviidae & Caulastrea furcata \\
\hline & Nubeculariidae & Vertebralina striata & $N$ & & Cyphastrea spp. \\
\hline & Soritidae & Marginopora vertebralis & Dino. & & Diploastrea heliopora \\
\hline & & Sorites orbiculus & Dino. & & Echinopora spp. \\
\hline & & Parasorites spp. & Greenalgae & & Favia spp. \\
\hline & & Peneroplis antillarum & Red Algae & & Favites spp. \\
\hline & & Peneroplis pertusus & Red Algae & & Goniastrea spp. \\
\hline & & Peneroplis planatus & Red Algae & & Leptastrea spp. \\
\hline & Spiroloculinidae & Spiroloculina angulata & $N$ & & Leptoria phrygia \\
\hline & & Spiroloculina corrugate & $N$ & & Montastrea spp. \\
\hline & & Spiroloculina faveolata & $N$ & & Moseleya latistellata \\
\hline & & Spiroloculina other & $N$ & & Oulophyllia spp. \\
\hline \multirow[t]{21}{*}{ Rotaliida } & Alfredinidae & Epistomaroides polystomelloides & $N$ & & Platygyra spp. \\
\hline & Amphisteginidae & Amphistegina radiata & Diatom & & Plesiastrea versipora \\
\hline & & Amphistegina spp. & Diatom & Fungiidae & Ctenactis crassa \\
\hline & Bagginidae & Cancris sp. & $N$ & & Fungia spp. \\
\hline & Calcarinidae & Baculogypsina sphaerulata & Diatom & & Heliofungia actiniformis \\
\hline & & Calcarina hispida & Diatom & & Herpolitha limax \\
\hline & & Calcarina mayorii & Diatom & & Podabacia crustacean \\
\hline & & Calcarina spengleri & Diatom & & Polyphyllia talpina \\
\hline & & Neorotalia calcar & Diatom & & Sandalolitha robusta \\
\hline & Cibicidae & Cibicides & $N^{*}$ & Merulinidae & Hydnophora spp. \\
\hline & Cymbaloporidae & Cymbalporetta spp. & $N$ & & Merulina ampliata \\
\hline & Discorbidae & Rosalina & $N$ & & \\
\hline & & Rotorbis & $N$ & Mussidae & Acanthastrea spp. \\
\hline & Elphidiidae & Elphidium cf. craticulatum & Plastids* & & Lobophyllia spp. \\
\hline & & Elphidium crispum & Plastids* & & Scolymia spp. \\
\hline & & Elphidium reticulosum & Plastids* & & Symphyllia spp. \\
\hline & Eponididae & Eponides sp. & None & Oculinidae & Galaxea spp. \\
\hline & Nummunlitidae & Heterostegina depressa & Diatoms & Pectiniidae & Echinophyllia spp. \\
\hline & & Operculina ammonoides & Diatoms & & Mycedium elephantotus \\
\hline & Planorbulinidae & Planorbulina sp. & $N$ & & Oxypora spp. \\
\hline & Reussellidae & Reussella & $N$ & & Pectinia spp. \\
\hline
\end{tabular}


Table 1 continued

\begin{tabular}{|c|c|c|c|c|c|}
\hline \multicolumn{4}{|l|}{ Foraminifera } & \multicolumn{2}{|l|}{ Corals } \\
\hline Order & Family & Species & Symbionts & Family & Taxon \\
\hline & Rotaliidae & Ammonia sp. & $N^{*}$ & Pocilloporidae & Pocillopora spp. \\
\hline & & Pararotalia sp. & $N^{*}$ & & Seriatopora hystrix \\
\hline & & Pararotalia venusta & $N^{*}$ & & Stylophora pistillata \\
\hline & & & $N$ & Poritidae & Alveopora spp. \\
\hline \multirow[t]{6}{*}{ Textulariida } & Textularidae & Textularia spp. & $N$ & & Goniopora spp. \\
\hline & & & & & Porites. spp. \\
\hline & & & & & Porites rus \\
\hline & & & & Siderastreidae & Coscinaraea columna \\
\hline & & & & & Psammocora spp. \\
\hline & & & & & Pseudosiderastrea tayami \\
\hline
\end{tabular}

Most corals were determined to genus level or species level, some genera were divided into growth forms. The type of symbiont is indicated for symbiont-bearing foraminifera. $N=$ no symbionts, Dino. dinoflagellate. Species regarded as opportunistic for calculation of the FORAM index are marked with an asterisk in the "Symbionts" column

hispida (6.5\%), Amphistegina radiata (5.0\%), and Baculogypsina sphaerulata $(4.1 \%)$.

Foraminiferal assemblages on reefs sampled in both 2005 and 2006 (24 reefs) had similar spatial patterns (Mantel test, rho $=0.761, p<0.001$ ), and data were averaged over the 2 years for all subsequent analyses.

Analysis of Similarities (ANOSIM) indicated significant differences in the foraminiferal assemblage composition between the geographical regions (Global $R=0.381$, $p<0.001)$. Pairwise tests indicated that, with the exception of the Wet Tropics and Burdekin regions $(R=-0.041$, $p=0.602$ ), all pairs of regions were significantly different from each other (all $R$ values between 0.377 and $0.857, p$ in each case $<0.017$ ); this pattern is illustrated by a non-metric multi-dimensional scaling plot (NMDS, Fig. 2a).

Average within-region similarity of foraminiferal assemblages ranged from about 63 to $77 \%$ whereas between-region dissimilarities ranged from 34 to $43 \%$ [Similarity Percentage (SIMPER) analyses, Table 2]. All abundant species were also among the species contributing most to the regional differences (Table 2). Most strikingly, C. mayori and B. sphaerulata were abundant in the two northernmost regions and absent or rare in the Whitsundays and Fitzroy regions. This pattern was reversed for Quinqueloculina spp., which was more abundant in the latter two regions. However, several rarer foraminifera were also important to distinguish individual regions, e.g., Discorbinella spp. was much more dominant in the Fitzroy Region compared to the other regions, and Cymbaloporetta spp., Pararotalia sp., and Miliolinella sp. were found exclusively in the Whitsunday Region (Table 2).

Taxa Richness (S) for the foraminiferal assemblages varied between individual locations, ranging from 14 to 43 (Table 3 ). The average was distinctly higher in the
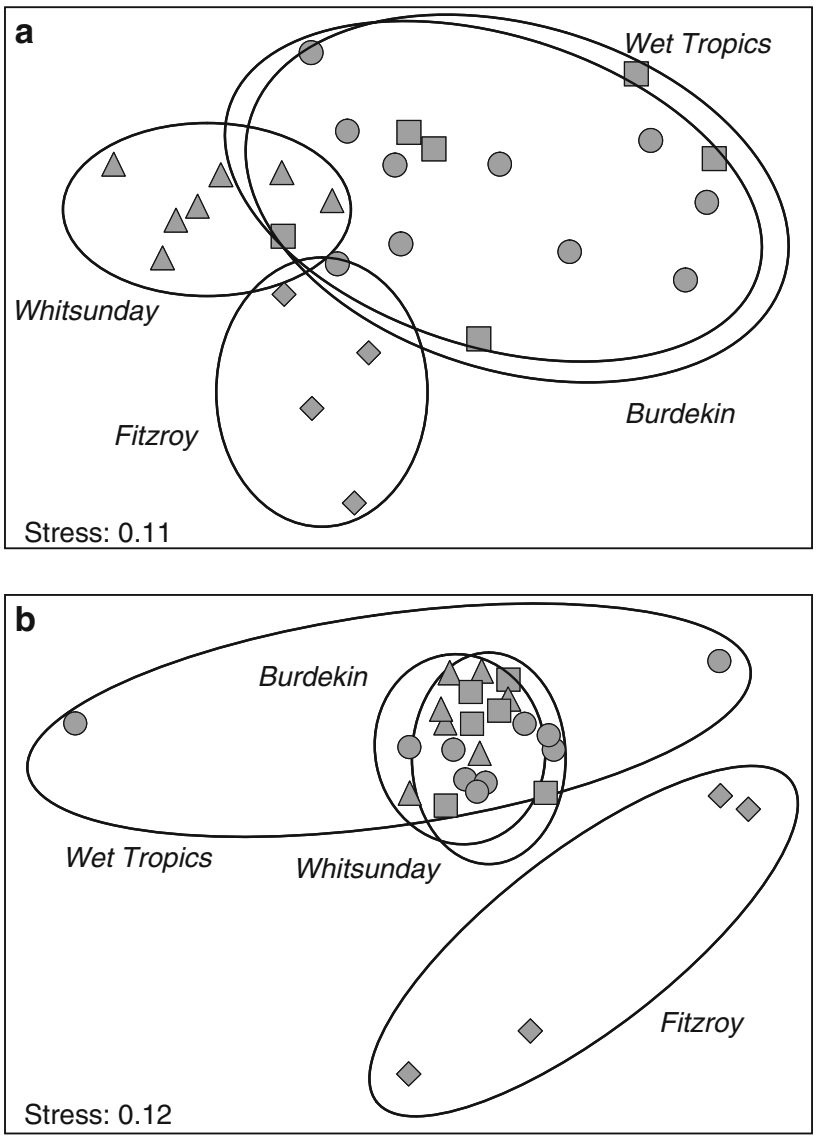

Fig. 2 Non-metric multi-dimensional scaling of foraminiferal (a) and hard-coral assemblages (b) in four inshore regions (Wet Tropics Region: circles; Burdekin Region: squares, Whitsunday Region: triangles, Fitzroy Region: diamonds) of the Great Barrier Reef. For clarity, ellipses were drawn around reefs in each region

Whitsunday Region compared to the three other regions, and the lowest taxa richness was observed in the Fitzroy Region at the southern end of the GBR. 
Table 2 Similarity percentage (SIMPER) analysis of foraminiferal assemblages in four inshore regions of the Great Barrier Reef

\begin{tabular}{|c|c|c|c|c|}
\hline & Wet tropics & Burdekin & Whitsunday & Fitzroy \\
\hline \multicolumn{5}{|l|}{ (A) SIMPER } \\
\hline Wet tropics Region & 65.39 & 34.45 & 42.80 & 40.66 \\
\hline Burdekin Region & $\begin{array}{l}\text { B. sphaerulata (5.66) } \\
\text { Quinqueloculina spp. (3.11) } \\
\text { Discorbinella } \text { sp. (3.01) } \\
\text { P. planatus }(2.85) \\
\text { P. venusta }(2.85)\end{array}$ & 62.94 & 41.73 & 42.45 \\
\hline Whitsunday Region & $\begin{array}{l}\text { C. mayori }(6.51) \\
\text { P. venusta }(4.14) \\
\text { B. sphaerulata }(3.43) \\
\text { Spiroloculina angulata }(3.28) \\
\text { Pararotalia sp.(3.20) }\end{array}$ & $\begin{array}{l}\text { C. mayori }(6.52) \\
\text { P. venusta }(4.05) \\
\text { C. hispida }(3.82) \\
\text { Spiroloculina angulata }(3.77) \\
\text { B. sphaerulata }(3.51)\end{array}$ & 77.42 & 37.42 \\
\hline Fitzroy Region & $\begin{array}{l}\text { C. mayori }(9.98) \\
\text { Discorbinella } \mathrm{sp} .(6.16) \\
\text { B. sphaerulata }(4.48) \\
\text { P. venusta }(3.91) \\
\text { C. hispida }(3.81)\end{array}$ & $\begin{array}{l}\text { C. mayori }(9.37) \\
\text { Discorbinella } \mathrm{sp} .(6.25) \\
\text { C. hispida }(4.96) \\
\text { B. sphaerulata }(4.25) \\
\text { P. venusta }(3.51)\end{array}$ & $\begin{array}{l}\text { Amphistegina. spp. (3.79) } \\
\text { Miliolinella sp. (3.77) } \\
\text { E. reticulosum (3.63) } \\
\text { Cymbaloporetta spp. } 2 \text { (3.41) } \\
\text { C. hispida (3.27) }\end{array}$ & 70.35 \\
\hline (B) Abundance & & & & \\
\hline B. sphaerulata & 5 & 10 & 0 & 0 \\
\hline C. hispida & 4 & 13 & 6 & 0 \\
\hline C. mayori & 36 & 34 & 2 & 0 \\
\hline Amphistegina spp. & 16 & 8 & 3 & 19 \\
\hline E. reticulosum & 0 & 0 & 2 & 0 \\
\hline Spiroloculina angulata & 0 & 0 & 3 & 1 \\
\hline Quinqueloculina spp. & 8 & 9 & 22 & 17 \\
\hline Discorbinella sp. & 0 & 0 & 3 & 12 \\
\hline P. planatus & 1 & 0 & 0 & 0 \\
\hline P. venusta & 1 & 1 & 10 & 4 \\
\hline Cymbaloporetta spp.2 & 0 & 0 & 2 & 0 \\
\hline Pararotalia sp. & 0 & 0 & 2 & 0 \\
\hline Miliolinella sp. & 0 & 0 & 2 & 0 \\
\hline
\end{tabular}

Above diagonal (in italics): Average dissimilarity (\%) between Regions; diagonal (in bold print): average within-region similarity (\%); below diagonal: five taxa contributing most to between-region dissimilarity, the contribution (\%) to the total dissimilarity of each taxon is given in brackets. Data were fourth root transformed. B: Average relative abundances (in \%, untransformed) of the taxa listed in Table 2 (A) in each region

Hard-coral assemblages

The most abundant coral genera at the sampling locations were Acropora (mean relative cover: 26.8\%) and Porites $(18.0 \%)$. Other common genera included Goniopora (9.7\%), Montipora (6.8\%), Turbinaria (4.5\%), and Galaxea $(3.6 \%)$. Similar to the foraminifera, coral assemblages had congruent spatial patterns in the two observation years (Mantel test, rho $=0.880, p<0.001$ ), and data were averaged over the two survey years for following analyses.

The coral assemblages significantly differed between the four geographical regions (global ANOSIM: $G=0.256$, $p=0.003$ ). Pairwise comparisons indicated that coral assemblages in the Fitzroy Region were markedly different than the other three regions $(R>0.58$ and, $p<0.020$ in each case). The coral communities in the Whitsunday Region differed from those in the Wet Tropics Region $(R=0.168, p=0.047)$, though neither of these regions differed from the communities on reefs in the Burdekin Region $(R=0.063, p=0.222$ for Whitsunday and $R=0.015, p=0.410$ for Wet Tropics; Fig. 2b).

Within-region similarity in coral communities was distinctly lower in the Fitzroy Region (about 37\%) compared with the other three regions (52-61\%, SIMPER, Table 4). 
Table 3 Richness (S) for foraminiferal assemblages (taxa defined in Table 1) and coral communities (genus level) on nearshore reefs in four regions of the Great Barrier Reef

\begin{tabular}{|c|c|c|}
\hline Location & Foraminifera & Corals \\
\hline \multicolumn{3}{|l|}{ Wet tropics Region } \\
\hline Dunk Isl. B & 30 & 26 \\
\hline Dunk Isl. F & 23 & 25 \\
\hline Fitzroy Isl. B & 34 & 35 \\
\hline Fitzro Isl. F & 15 & 29 \\
\hline Frankland Isl. B & 31 & 8 \\
\hline Frankland Isl. F & 27 & 12 \\
\hline High Isl. B & 38 & 26 \\
\hline High Isl. F & 18 & 28 \\
\hline King Rf. & 14 & 16 \\
\hline North Barnard Isl. & 32 & 22 \\
\hline Average (SD) & $26.2(8.3)$ & $22.7(8.3)$ \\
\hline \multicolumn{3}{|l|}{ Burdekin Region } \\
\hline Geoffrey Bay & 33 & 32 \\
\hline Havannah Isl. & 35 & 29 \\
\hline Lady Elliot Isl. & 24 & 27 \\
\hline Orpheus Isl. & 20 & 17 \\
\hline Pandora Rf. & 14 & 26 \\
\hline Pelorus Isl. & 34 & 26 \\
\hline Average (SD) & $26.7(8.7)$ & $26.2(5.0)$ \\
\hline \multicolumn{3}{|l|}{ Whitsunday Region } \\
\hline Daydream Isl. & 33 & 23 \\
\hline Dent Isl. & 40 & 36 \\
\hline Double Cone Isl. & 37 & 33 \\
\hline Hook Isl. & 43 & 27 \\
\hline Pine Isl. & 34 & 34 \\
\hline Seaforth Isl. & 35 & 27 \\
\hline Shute and Tancred Isl. & 36 & 25 \\
\hline Average (SD) & $36.9(3.5)$ & $29.3(5.0)$ \\
\hline \multicolumn{3}{|l|}{ Fitzroy Region } \\
\hline Humpy Isl. & 23 & 10 \\
\hline North Keppel Isl. & 29 & 7 \\
\hline Peak Isl. & 18 & 13 \\
\hline Pelican Isl. & 22 & 25 \\
\hline Average (SD) & $23.0(4.5)$ & $13.8(7.9)$ \\
\hline
\end{tabular}

Average and standard deviation (SD) are given for each region. $B$ back reef, $F$ front reef

As suggested by the ANOSIM and NMDS, between-region dissimilarity in coral communities was largest between Fitzroy Region and the other three regions (Table 4). The most striking difference between coral communities in Fitzroy Region and the remaining regions was the higher representation of branching Acropora and Goniastrea and the absence of a number of genera found in the other regions (Table 4). The highest hard-coral richness was observed in the Whitsunday Region, and diversity was lowest the Fitzroy Region (Table 3).

Relationship of hard-coral and foraminiferal assemblages with water and sediment quality

The observed spatial patterns for foraminiferal and coral assemblages showed significant similarity (Mantel test, rho $=0.208, p=0.05$ ).

Redundancy analysis (RDA) was used to assess taxalocation relationships and the effects of environmental variables. A significant amount of variation in the foraminiferal distribution (Table 5) was explained by the proportion of very fine sands and fine sands (63-250 $\mu \mathrm{m}$ grain size) and clays and silts $(<63 \mu \mathrm{m})$, sediment organic matter and inorganic carbon content and the composite water column particulate variable. Thirty-five per cent of the variation in the foraminiferal distribution was explained after partialling out effects of 'Region' (Fig. 3), and the five environmental parameters explained an additional 27.7\%. Heterotrophic foraminifera were associated with high values of 'particulates' in the water and fine sediments ( $<63$ and $63-250 \mu \mathrm{m}$ grain size) with high sediment organic carbon and nitrogen content (Fig. 3). In contrast, symbiont-bearing species were associated with low turbidity and high inorganic carbon content in the sediment. Heterotrophic and symbiont-bearing foraminiferal species were well separated along the first two RDA axes, with only a small area of overlap (Fig. 3). Most of this overlap was due to two Peneroplis species, the two main taxa bearing red algal endosymbionts (see Table 1 for symbiont types of all taxa). All diatom-bearing species were clearly separated from heterotrophic taxa, whereas the dinoflagellate-bearing species contributed little to the differences in assemblage composition between reefs, possibly because of their generally low abundance in most samples.

This pattern was confirmed by multiple regression analyses, which indicated that a large amount of the variation in the FORAM index (89\%) and foraminiferal taxa richness $(61 \%)$ was explained by a subset of the measured environmental parameters (Table 6). The FORAM index (high values $=$ high relative abundance of symbiont-bearing taxa) decreased with increasing proportions of sediments with small grain sizes and high organic matter content and with increasing concentrations of water column particles (and hence reduced light availability). In contrast, this index increases with increasing values of sediment inorganic carbon and increasing hard-coral cover (Table 6). Variation in foraminiferal taxa richness was also explained by environmental parameters and mainly increased with increasing proportion of sediments with small grain sizes (Table 6). 
Table 4 (A) Similarity percentage (SIMPER) analysis for coral assemblage composition in four nearshore regions of the Great Barrier Reef

\begin{tabular}{|c|c|c|c|c|}
\hline & Wet tropics & Burdekin & Whitsunday & Fitzroy \\
\hline \multicolumn{5}{|l|}{ (A) SIMPER } \\
\hline Wet tropics Region & 51.92 & 45.19 & 47.75 & 68.05 \\
\hline \multirow[t]{5}{*}{ Burdekin Region } & Porites rus (4.24) & & & \\
\hline & Porites Branching (3.28) & 59.45 & 40.88 & 64.99 \\
\hline & Turbinaria (3.22) & & & \\
\hline & Diploastrea (2.85) & & & \\
\hline & Merulina (2.76) & & & \\
\hline \multirow[t]{5}{*}{ Whitsunday Region } & Porites rus (4.17) & Galaxea (3.18) & & \\
\hline & Goniopora (3.34) & Acropora Bottlebrush (3.15) & 61.15 & 65.75 \\
\hline & Acropora Branching (3.27) & Porites Branching (3.05) & & \\
\hline & Pectinia (3.20) & Diploastrea (3.04) & & \\
\hline & Porites Branching (3.02) & Acropora Branching (2.99) & & \\
\hline \multirow[t]{5}{*}{ Fitzroy Region } & Acropora Branching (6.21) & Acropora Branching (5.05) & Goniopora (5.06) & \\
\hline & Porites rus (4.37) & Porites Massive (4.01) & Acropora Branching (5.03) & 36.8 \\
\hline & Porites Massive (3.57) & Galaxea (3.74) & Pectinia (3.83) & \\
\hline & Porites Branching (3.24) & Goniopora (3.61) & Pachyseris (3.42) & \\
\hline & Goniastrea (3.18) & Merulina (3.41) & Porites Massive (3.14) & \\
\hline \multicolumn{5}{|l|}{ (B) rel. cover } \\
\hline Acropora Bottlebrush & 1.1 & 1.1 & 3.1 & 0.05 \\
\hline Acropora Branching & 3.1 & 4.8 & 13.9 & 57.5 \\
\hline Diploastrea & 0.6 & 4.6 & 1.5 & 0 \\
\hline Galaxea & 2.1 & 7.5 & 3.8 & 0.05 \\
\hline Goniastrea & 2.9 & 2.7 & 0.6 & 9.6 \\
\hline Goniopora & 2.8 & 6.4 & 24.8 & 1.4 \\
\hline Merulina & 1.2 & 3.2 & 0.9 & 0 \\
\hline Pachyseris & 1.3 & 4.0 & 2.8 & 0 \\
\hline Pectinia & 0.5 & 2.1 & 4.9 & 0 \\
\hline Porites Branching & 6.5 & 2.1 & 2.7 & 0 \\
\hline Porites Massive & 8.1 & 9.9 & 7.1 & 0.2 \\
\hline Porites rus & 16.7 & 0.4 & 0 & 0 \\
\hline Turbinaria & 6.0 & 5.7 & 1.2 & 4.9 \\
\hline
\end{tabular}

Above diagonal (in italics): Average dissimilarity (\%) between regions; diagonal (in bold print): average within-region similarity (\%); below diagonal: five taxa contributing most to between-region dissimilarity, the contribution (\%) to the total dissimilarity of each taxon is given in brackets. Data were fourth root transformed for analyses. (B) Average relative cover (in \%, untransformed) of the taxa listed in (A) in each region

Coral assemblage composition was also related to environmental parameters (Table 5). The proportions of sediments with small grain sizes $(<63 \mu \mathrm{m}$ and between $63-$ $250 \mu \mathrm{m})$, the combined organic carbon and nitrogen content of the sediment and the composite water column parameter 'particulates' explained most of the variation in coral assemblage composition (Table 5). Twenty-five per cent of the variation in coral assemblage composition was explained after partialling out the effects of 'Region' (Fig. 4), and the environmental parameters explained an additional $27 \%$. Several coral genera were associated with low light availability as inferred by high values of water column particulates (Fig. 4, e.g., Hydnophora, Turbinaria,
Goniastrea, and Moseleya). In contrast, branching and corymbose forms of Acropora were more common on reefs with lower values of particulates in the water column and, hence, more light availability. Some coral taxa were generally associated with sediments of small grain sizes, high organic carbon and nitrogen content (e.g., Pachyseris, Porites rus and branching Porites, and the unattached Fungia and Ctenactis). Another group of coral taxa (e.g., massive Porites and Diploastrea) was negatively correlated with fine sediments, but exhibited no obvious relationship with light. There was no significant relationship between the richness of coral genera and any of the environmental parameters (multiple regression analyses, Table 6). 
Table 5 The amount of variance explained (\%) by individual environmental parameters in a redundancy analysis of foraminiferal and coral assemblage data

The effect of region was partialled out for the test of each parameter. Pseudo-F and $\mathrm{p}$ values test the significance of each variable in permutation tests (1,000 permutations). Bold print: parameters significant at $p<0.10$, and used in final analyses (see Figs. 3, 4). - The effect of coral cover on coral communities was not analysed

\begin{tabular}{|c|c|c|c|c|c|c|}
\hline \multirow{2}{*}{ Variables } & \multicolumn{3}{|c|}{ Foraminifera } & \multicolumn{3}{|l|}{ Corals } \\
\hline & Pseudo-F & $p$ & $\%$ Explained & Pseudo-F & $p$ & $\%$ Explained \\
\hline \multicolumn{7}{|l|}{ Sediment } \\
\hline Grain size $(0-63 \mu \mathrm{m})$ & 2.33 & $\mathbf{0 . 0 5 3}$ & 6.46 & 2.02 & 0.086 & 6.58 \\
\hline Grain size $(63-250 \mu \mathrm{m})$ & 5.61 & $<0.001$ & 13.61 & 5.44 & 0.001 & 15.46 \\
\hline Organic $\mathrm{C}$ and $\mathrm{N}$ & 2.81 & 0.029 & 7.61 & 3.86 & 0.007 & 11.66 \\
\hline Inorganic $\mathrm{C}$ & 2.37 & 0.062 & 6.55 & 0.82 & 0.44 & 2.84 \\
\hline \multicolumn{7}{|l|}{ Water column } \\
\hline Particulates & 2.75 & 0.029 & 7.49 & 3.1 & 0.001 & 9.67 \\
\hline TDN & 1.07 & 0.355 & 3.14 & 0.69 & 0.597 & 2.38 \\
\hline TDP & 1.41 & 0.164 & 4.07 & 0.87 & 0.436 & 3.0 \\
\hline Salinity & 1.51 & 0.160 & 4.33 & 1.14 & 0.3 & 3.88 \\
\hline \multicolumn{7}{|l|}{ Surrounding benthos } \\
\hline Hard-coral cover & 0.99 & 0.361 & 2.91 & - & - & - \\
\hline
\end{tabular}

Fig. 3 Redundancy analysis (RDA) of foraminiferal relative abundances on 26 inshore reefs of the Great Barrier Reef. Only the $40 \%$ of the taxa vectors which contributed most to the assemblage differences are shown. Data were fourth root transformed and row centred. Polygons surround symbiontbearing and aposymbiotic species, respectively. Only environmental variables (bold lines with arrow heads) explaining a significant amount of the variation (see Table 5) were included (see Fig. 1 for abbreviations)

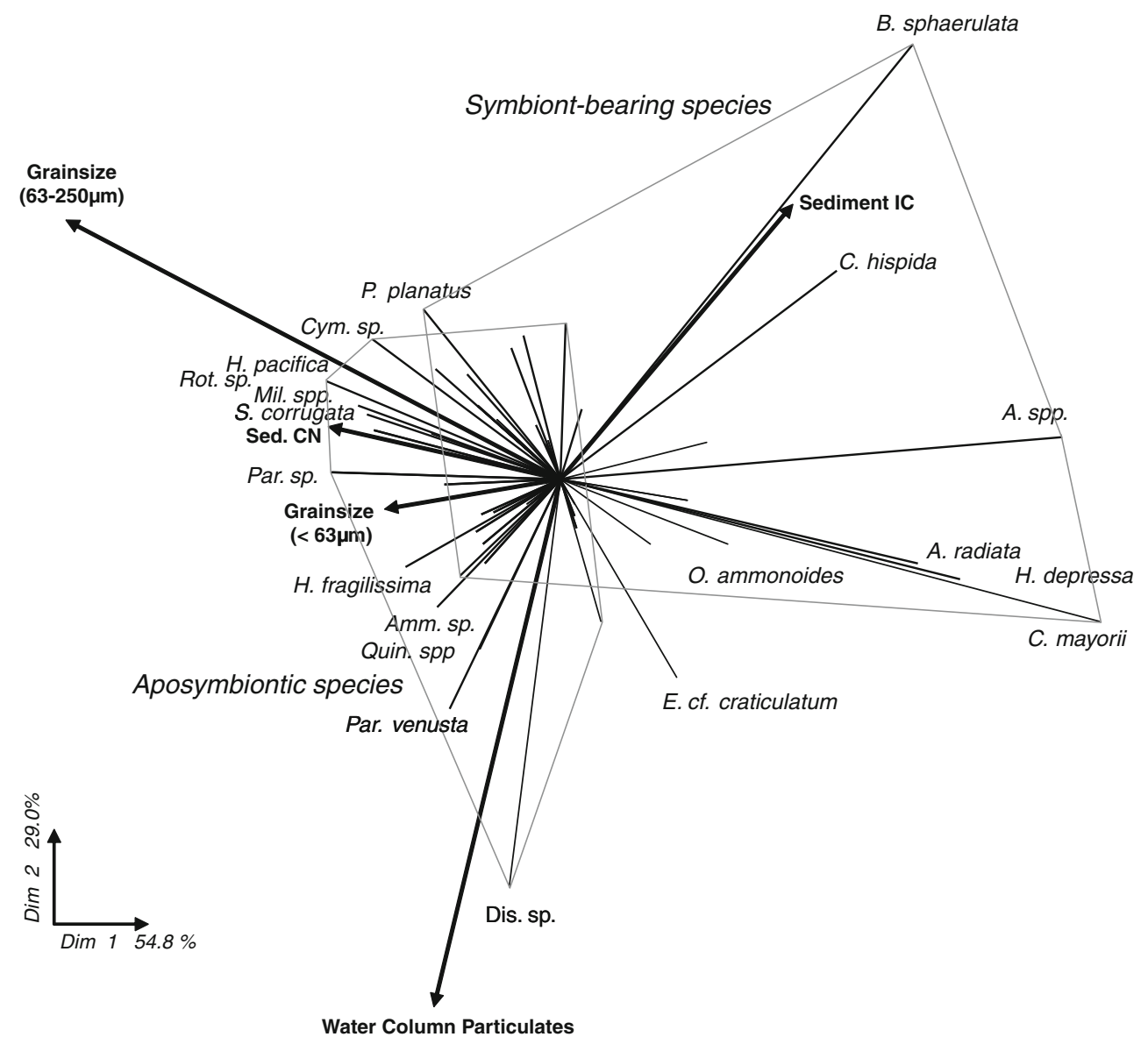

\section{Discussion}

This study investigated differences in assemblage composition of both foraminifera and hard corals on inshore reefs of the Great Barrier Reef (GBR) and their relationship with water quality and sediment characteristics. We argue below that assemblage composition of foraminifera, but not of corals, is a useful indicator of short-term (years) changes in environmental quality. Foraminifera are likely to respond faster to changes in water quality and are less susceptible to acute catastrophic disturbances. In contrast, coral data are more difficult to interpret because they are shaped by acute disturbances, and surprisingly little is known about the basic ecology of individual species. 
Table 6 Multiple regression analyses for FORAM index and foraminiferal and coral genus richness

\begin{tabular}{|c|c|c|c|c|c|c|c|c|c|}
\hline \multirow[t]{2}{*}{ Variables } & \multicolumn{3}{|c|}{ FORAM index } & \multicolumn{3}{|c|}{ Foraminiferal richness } & \multicolumn{3}{|c|}{ Coral richness } \\
\hline & Slope & $t$ & $p$ & Slope & $t$ & $p$ & Slope & $t$ & $p$ \\
\hline \multicolumn{10}{|l|}{ Sediment } \\
\hline Grain size $(0-63 \mu \mathrm{m})$ & Ex & & & 4.13 & 2.17 & 0.042 & 3.45 & 2.05 & 0.052 \\
\hline Grain size $(63-250 \mu \mathrm{m})$ & -0.85 & -3.62 & 0.001 & 5.03 & 1.39 & 0.002 & -3.29 & -1.95 & 0.062 \\
\hline Organic $\mathrm{C}$ and $\mathrm{N}$ & -1.59 & -4.79 & $<0.001$ & Ex & & & Ex & & \\
\hline Inorganic $\mathrm{C}$ & 1.06 & 3.76 & 0.001 & 3.11 & 1.76 & 0.094 & Ex & & \\
\hline \multicolumn{10}{|l|}{ Water column } \\
\hline Particulates & -0.39 & -1.48 & 0.154 & 3.38 & 2.01 & 0.057 & Ex & & \\
\hline TDN & Ex & & & Ex & & & Ex & & \\
\hline TDP & Ex & & & 2.53 & 1.77 & 0.093 & Ex & & \\
\hline Salinity & Ex & & & Ex & & & Ex & & \\
\hline \multicolumn{10}{|l|}{ Surrounding benthos } \\
\hline Hard-coral cover & 0.94 & 3.90 & $<0.001$ & Ex & & & - & - & - \\
\hline Intercept: total model & 6.49 & 35.14 & $<0.001$ & 29.00 & 25.82 & $<0.001$ & 24.27 & 16.42 & $<0.001$ \\
\hline$R^{2}$ & 0.89 & & & 0.61 & & & 0.20 & & \\
\hline$p$ & $<0.001$ & & & $<0.001$ & & & 0.082 & & \\
\hline
\end{tabular}

All environmental variables were initially included in each model, and terms subsequently eliminated through stepwise backwards elimination. $E x$ term excluded by backwards elimination. Coral cover was not included in the coral richness model

Fig. 4 Redundancy analysis (RDA) of relative coral cover on 26 inshore reefs of the Great Barrier Reef. Only the $30 \%$ of the taxa vectors which contributed most to the assemblage differences are shown. Data were fourth root transformed and row centred. Only environmental variables (bold lines with arrow heads) explaining a significant amount of the variation (see Table 5) were included in this analysis (see Fig. 1 for abbreviations)

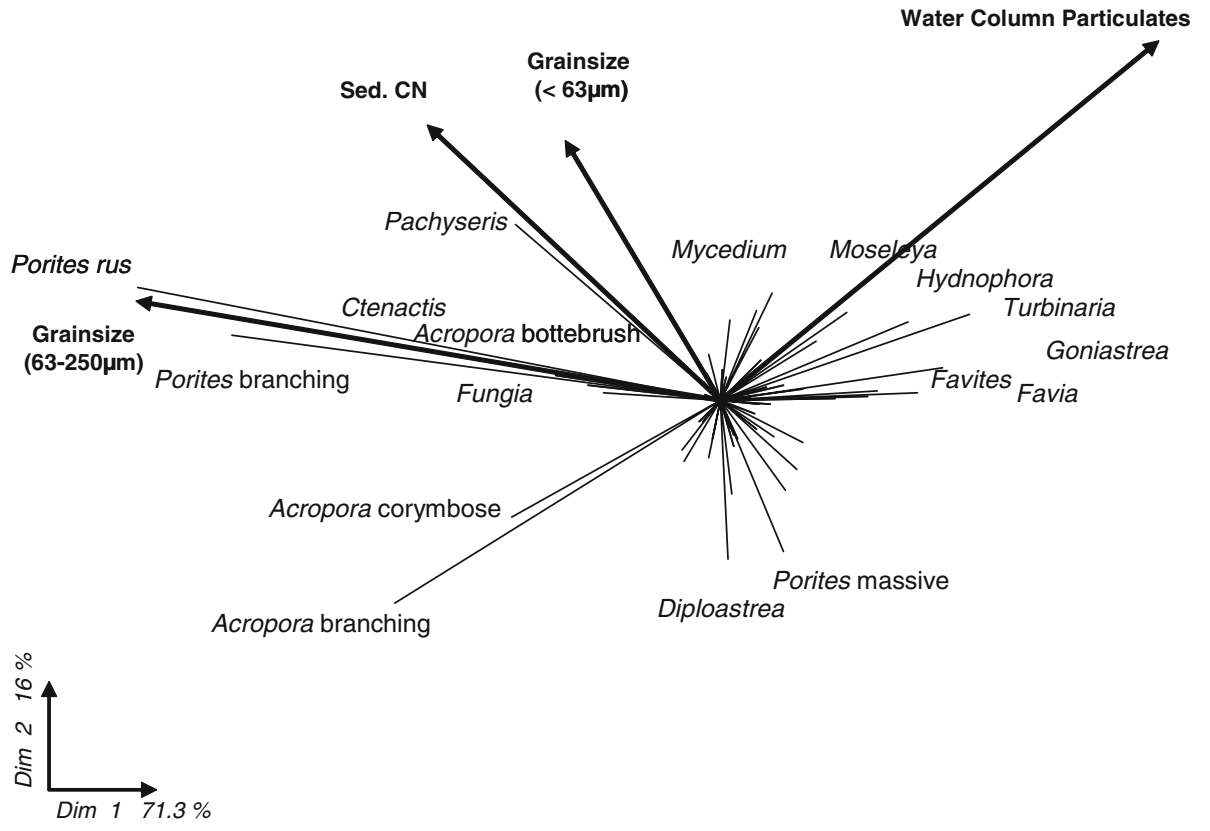

\section{Foraminifera}

Foraminiferal assemblage composition differed between study regions, confirming a previous comparison between three inshore GBR regions and midshelf reefs (Uthicke and Nobes 2008). The distribution of benthic foraminifera is influenced by a variety of factors such as water flow, depth, microhabitat and substratum type, salinity fluctuations and pollutants (e.g., Alve 1995; de Rijk 1995; Renema and
Troelstra 2001; Renema 2006). In addition, food availability can be a limiting factor for heterotrophic benthic foraminifera (Jorissen 2002). In the present study, the influence of depth and microhabitat was minimised by collecting at a standard depth and focusing on sediment assemblages that integrate over several microhabitats as they represent living foraminifera on the sediment and recently dead ones from sediments and other microhabitats (Uthicke and Nobes 2008). 
Most striking was the decline of the genera Baculogypsina and Calcarina from North to South. The relative abundance of these groups was 45 and $57 \%$ in the Wet Tropics and Burdekin regions, respectively, and declining to $1 \%$ (Fitzroy Region) towards the South. Other species increased towards the south (e.g., Discorbinella spp., Quinqueloculina spp.). Regions were located along a latitudinal, and hence, temperature gradient, while differences in water flow, a consequence of different tidal regimes, are also likely to be important. Winter water temperatures in the Fitzroy and Whitsunday regions are regularly below distributional limits given for Calcarina spp. $\left(23^{\circ} \mathrm{C}\right)$ and Baculogypsina sphaerulata $\left(21^{\circ} \mathrm{C}\right.$; Langer and Hottinger 2000), but these species have been observed on outer shelf reefs at similar latitude (Schueth and Frank 2008); suggesting that other factors such as habitat availability influence the distribution of these species.

Several environmental parameters explained variation in the foraminiferal assemblage composition after removing the effects of 'Region'. Heterotrophic and symbiont-bearing foraminiferal species separated in two distinct groups with little overlap, roughly determined by sediment grain size, nutrient content and light availability, similar to a previous study on other GBR reefs (Uthicke and Nobes 2008). In addition, high FORAM indices (Hallock et al. 2003) were associated with sediments with larger grain sizes, high inorganic carbon content, higher light availability and low amounts of particulates in the water column. Variation in foraminiferal taxa richness was mainly explained by an increase in the proportion of sediments with small grain sizes. While sediment grain size and inorganic carbon content are unlikely to be directly influenced by terrestrial runoff, the input, transformation, and retention of terrestrial nutrients, and suspended sediments can result in high organic sediment content and decreased light availability (Uthicke 2006; Cooper et al. 2007).

The combined water quality parameter 'particulates', representing light availability and organic matter load, was negatively correlated with the abundance of symbiontbearing species such as $B$. sphaerulata and $C$. hispida. These species have been described as photophilic species, often occurring at shallow depths (Hohenegger 1994; Hohenegger et al. 1999; Lobegeier 2002). In contrast, the relative abundance of the diatom-bearing species Amphistegina radiata, Heterostegina depresssa, and C. mayori were independent of light availability, confirming results by Nobes et al. (2008). All three species are usually found in deeper water or shaded microhabitats, e.g., under coral rubble (Haunold et al. 1997; Hohenegger et al. 1999; Cleary and Renema 2007).

Diatom-bearing species contributed mostly to the distinction between heterotrophic and symbiont-bearing foraminifera and the respective environmental conditions they indicated. Dinoflagellate-bearing species did not contribute much to assemblage differences, possibly because of their low relative abundance in our samples. The distinction between the two trophic groups is even clearer when the two red algae-bearing species Peneroplis planatus and $P$. pertusus were removed (results not shown). These species were abundant on reefs characterised by sediments with small grain sizes and high organic matter and low light availability, which were generally dominated by heterotrophic species in our analyses. Little is known about the ecology of the red algae-bearing species, but they seem to occur on a variety of substrate types and depths, preferring sheltered areas (Renema 2003) and sandy substrata (Renema and Troelstra 2001; Cleary and Renema 2007). Perhaps, similar to Elphidium spp. which retain chloroplasts from algal food (Renema and Troelstra 2001), these species are less dependent on autotrophic production than diatom or dinoflagellate-bearing species. Fine-tuning of the FORAM index will require further studies of foraminiferal ecology, especially with regard to host-symbiont relationships.

Coral cover was positively related to the FORAM index in the inshore reefs investigated. While this could be interpreted as additional support for the validity of the FORAM index as an indicator for reef health, further work over longer time scales is required to test whether the FORAM index would also track changes in coral cover over time.

\section{Corals}

Similar to foraminiferal assemblages, coral assemblage composition varied between regions. This difference was largely because of the absence or relative rarity of a number of genera in the southernmost Fitzroy Region. Lower richness observed in the Fitzroy Region is consistent with generally declining coral richness with increasing latitude in the GBR (DeVantier et al. 2006). However, the slight differences in hard-coral assemblages among the three northern regions may be influenced by factors other than latitude, for example, the recent disturbance history and susceptibility of several coral species to acute disturbances. Disturbance alone can strongly alter coral assemblage composition (e.g., Done et al. 2007; Connell et al. 2004), and we suggest that disturbance history influences assemblage composition at regional scales and for substantial periods of time.

The communities here were surveyed about 5-9 years after major disturbance events. For example, during the 1990s, several of the Wet Tropics reefs were affected by crown-of-thorns seastar (Acanthaster planci) predation (Fabricius et al. 2005). Branching Porites (mostly P. cylindrica) and $P$. rus were two of the five taxa explaining 
most of the variation in the data among regions and had higher abundances in the Wet Tropics. Acanthaster planci avoid $P$. cylindrica as prey (Pratchett 2007) and have not been observed to prey on $P$. rus in many years of targeted surveys (A. Thomson, pers. obs.). Conversely, Acropora and Pectinia, which belong to families highly susceptible to A. planci predation (Keesing 1990), were more common on inshore Whitsundays reefs, which did not experience A. planci outbreaks.

In 1998 and 2002, mass coral bleaching affected many inshore reefs (Berkelmans et al. 2004). The 1998 bleaching event resulted in mortality of susceptible species at several reefs in the Burdekin and Wet Tropics regions but not so in the Whitsunday region (Marshall and Baird 2000; Sweatman et al. 2007). In these two regions, the genera Galaxea, Diploastrea and Turbinaria, which have low susceptibility to bleaching remain proportionally more common than in the Whitsunday Region where bleaching, though widespread in 2002 (Berkelmans et al. 2004), has caused minimal mortality (Sweatman et al. 2007).

Independent of these regional differences due to regions and acute disturbances, hard-coral assemblage composition varied in association with sediment grain size and nutrient content and levels of the combined water quality parameter 'particulates'. Coral genera associated with fine-grained sediments included Fungia and Pachyseris, taxa that are capable of rapidly removing silt from their tissue (StaffordSmith and Ormond 1992). Fungia crassa was also one of three species not affected by sedimentation in an experimental setting (Philipp and Fabricius 2003). Coral genera associated with higher turbidity included Oxypora, Mycedium, and Turbinaria. It appears that these species are generally sciaphillic because they prefer turbid waters (Done 1982) or are found in relatively low light settings (Titlyanov and Latypov 1991).

Part of the ability to exist in low light is due to the trophic plasticity of some corals, whereby reductions in photosynthetic energy in low light are compensated for by feeding on suspended particles (Anthony 2000), which extends the environmental niche of some corals into turbid environments (Anthony 2000; Anthony and Fabricius 2000; Anthony and Connolly 2004). The genera Goniastrea and Pocillopora were independent of turbidity/light availability in the present analyses. Energy acquisition in Goniastrea retiformis is highly variable, the species is found across a range of light regimes and enhanced heterotrophy in turbid environments compensates for limitation of photosynthesis by reduced light (Anthony and Fabricius 2000). Similarly, Pocillopora damicornis adjusts its energy acquisition mode depending on particle concentrations in the water column (Anthony 2000). Taxa in the family Pocilloporidae are regarded as pioneers, often re-growing faster than other taxa after physical disturbance
(Fabricius et al. 2005). In contrast, the genus Porites and corymbose and branching growth forms of Acropora were more abundant in low turbidity, high-light environments in the present study. Porites cylindrica has low photo and heterotrophic plasticity and depends more on photosynthesis for energy gain (Anthony and Fabricius 2000). There are fewer Acropora spp. inshore, representing a subset of the species suite on GBR offshore reefs (DeVantier et al. 2006). Done (1982) even classified GBR inshore reefs as 'non-Acropora' reefs, but we showed that some inshore reefs with high light availability have coral assemblages with a high relative abundance of Acropora spp., mostly of branching and corymbose growth forms. It is unclear whether the different coral assemblages reflect different environmental conditions, such as sedimentation and turbidity, or different disturbance histories. We suggest the observed assemblage composition at a given reef is the result of both past disturbances and the local environmental setting. Because adult coral colonies are typically less sensitive to water quality than juveniles (Fabricius 2005), existing colonies may persist in an environment in which their juveniles are unlikely to survive, or in which successful reproduction (e.g., fertilisation) is hampered through environmental conditions (Humphrey et al. 2008). Our analyses did not detect a direct relationship between environmental quality and coral generic richness. This may be due to the variable taxonomic resolution of our study (a mixture of genus, species, and growth form) compared with other studies using coral species richness (e.g., DeVantier et al. 2006). To use coral richness as an indicator of environmental change in diverse systems such as the central Indo-Pacific will require sampling of larger areas at high taxonomic resolution (e.g., through direct visual assessments and collections) to capture rare species.

\section{Comparison between foraminiferal and coral} assemblages

A similar suite of environmental parameters influenced the composition of both foraminiferal and coral assemblages. These include the proportion of fine-grained sediments, the organic carbon and nitrogen content of the sediment, and the amount of particles in the water column and associated light availability. However, the foraminiferal assemblage composition did not simply predict or track the coral assemblage composition, although a significant correlation did exist between the two assemblages.

Coral assemblages are very dynamic and constantly change due to acute disturbances such as cyclones, outbreaks of $A$. planci, coral bleaching and disease. Coral assemblages are also shaped by the chronic settings of their environment, which for example, influence coral recruitment and impede coral growth. As a result of acute and 
chronic causes, very different coral communities may occur at sites with similar environmental conditions. Thus, it is likely that a mosaic of coral assemblages with different acute disturbance histories obscures the perhaps more subtle effects of environmental quality that foraminifera detect.

Some of these acute disturbances, especially temperature and light conditions leading to bleaching, might also affect foraminiferal assemblages. However, it is unlikely that effects of cyclones, for instance, are as severe. In addition, smaller size and faster turnover will allow foraminiferal assemblages to recover and reach successional endpoints more rapidly. Although ecological studies on foraminiferal succession in the Pacific Region are lacking, ecological studies of symbiont-bearing foraminifera in the Florida reef tract have shown that populations recover from bleachingrelated mortality events or hurricane scouring in a matter of months to at most a year or two (Williams et al. 1997; Hallock et al. 2006, Baker et al. 2009). This is in contrast with coral communities which may need decades to fully recover colony density and diversity (Done et al. 2007; Wakeford et al. 2008). Indeed, paleontological data suggest that foraminiferal assemblages are much more persistent over time than coral assemblages (Tager et al. in press). In contrast, chronic disturbances in the environment such as nutrification can distinctly change foraminiferal assemblages and subsequently the FORAM index (Hallock et al. 2003).

We propose that foraminiferal assemblage composition, specifically the FORAM index, provides an effective bioindicator for the assessment of turbidity/light regimes and organic enrichment of sediments on coral reefs. While coral assemblage composition varied in different sediment and water quality conditions, we cannot fully interpret these changes or develop simple coral-based bioindicators for these environmental conditions, until the ecology of a wide range of coral taxa is better understood. However, future research and monitoring of coral population dynamics, especially recruitment and rate of recovery after disturbances under different environmental regimes, continues to be important, because hard-coral cover and diversity are important conservation targets. The wider application of other bioindicators, such as foraminiferal assemblage composition, which may be more sensitive and react faster to changes in water and sediment quality, will support reaching these conservation targets.

Acknowledgments We are grateful for the assistance of D. Thomson, S. Neale, F. Patell, and K. Nobes for collection and analysis of sediment, coral cover, and foraminiferal data. M. Cappo and E. Cripps provided statistical support for this work. K. Fabricius and two anonymous reviewers provided valuable comments on an earlier version of the MS. This study was funded by the Marine Tropical Strategic Research Facility funds of the Department of Environment, Water, Heritage and the Arts, and the Reef Water Quality Protection Plan Marine Monitoring Program, which was developed and run by the Great Barrier Reef Marine Park Authority and funded by the Australian Natural Heritage Trust.

Open Access This article is distributed under the terms of the Creative Commons Attribution Noncommercial License which permits any noncommercial use, distribution, and reproduction in any medium, provided the original author(s) and source are credited.

\section{References}

Alve E (1995) Benthic foraminiferal responses to estuarine pollution: a review. J Foraminifer Res 25:190-203

Anthony KRN (2000) Enhanced particle-feeding capacity of corals on turbid reefs (Great Barrier Reef, Australia). Coral Reefs 19: $59-67$

Anthony KRN, Connolly SR (2004) Environmental limits to growth: physiological niche boundries of corals along turbidity-light gradients. Oecologia 141:373-384

Anthony KRN, Fabricius KE (2000) Shifting roles of heterotrophy and autotrophy in coral energetics under varying turbidity. J Exp Mar Biol Ecol 252:221-253

Baker RD, Hallock P, Moses EF, Williams DE, Ramirez A (2009) Larger foraminifers of the Florida Reef Tract, USA: Distribution patterns on reef-rubble habitats. J Foraminifer Res 39:267-277

Bellwood DR, Hughes TP, Folke C, Nystroem M (2004) Confronting the coral reef crisis. Nature 429:827-833

Berkelmans R, De'ath G, Kininmonth S, Skirving WJ (2004) A comparison of the 1998 and 2002 coral bleaching events on the Great Barrier Reef: spatial correlation, patterns, and predictions. Coral Reefs 23:74-83

Brodie J, De'ath G, Devlin M, Furnas M, Wright M (2007) Spatial and temporal patterns of near-surface chlorophyll a in the Great Barrier Reef lagoon. Mar Freshw Res 58:342-353

Bruno JF, Selig ER (2007) Regional decline of coral cover in the Indo-Pacific: Timing, extent, and subregional comparisons. PLoS ONE 2:e711

Clarke KR, Gorley RN (2001) Primer v5: User manual/tutorial. Primer-E, Plymouth, p 91

Cleary DFR, Renema W (2007) Relating species traits of Foraminifera to environmental variables in the Spermonde Archipelago, Indonesia. Mar Ecol Prog Ser 334:73-82

Connell JH, Hughes TP, Wallace CC, Tanner JE, Harms KE, Kerr AM (2004) A long-term study of competition and diversity of corals. Ecol Monogr 74:179-210

Cooper T, Fabricius KE (2007) Coral-based indicators of changes in water quality on nearshore coral reefs of the Great Barrier Reef. Report prepared for Marine and Tropical Sciences Research Facility, Reef and Rainforest Research Centre Ltd: Cairns

Cooper T, Uthicke S, Humphrey C, Fabricius K (2007) Gradients in water column nutrients, sediments, irradiance and coral reef development in the Whitsunday Region, central Great Barrier Reef. Estuar Coast Shelf Sci 74:458-470

de Rijk S (1995) Salinity control on the distribution of salt marsh Foraminifera (Great Marshes, Massachusetts). J Foraminifer Res 25:156-166

DeVantier L, De'ath G, Turak E, Done T, Fabricius K (2006) Species richness and community structure of reef-building corals on the nearshore Great Barrier Reef. Coral Reefs 25:329-340

Done TJ (1982) Patterns in the distribution of coral communities across the central Great Barrier Reef. Coral Reefs 1:95-107

Done T, Turak E, Wakeford M, DeVantier L, McDonald A, Fisk D (2007) Decadal changes in turbid-water coral communities at 
Pandora Reef: loss of resilience or too soon to tell? Coral Reefs: $1-17$

Fabricius KE (2005) Effects of terrestrial runoff on the ecology of corals and coral reefs: review and synthesis. Mar Pollut Bull 50:125-146

Fabricius KE, De'ath G (2008) Photosynthetic symbionts and energy supply determine octocoral biodiversity in coral reefs. Ecology 89:3163-3173

Fabricius K, De'ath G, McCook L, Turak E, Williams DM (2005) Changes in algal, coral and fish assemblages along water quality gradients on the inshore Great Barrier Reef. Mar Pollut Bull 51:384-398

Fabricius KE, Hoegh-Guldberg O, Johnson J, McCook L, Lough J (2007) Vulnerability of coral reefs of the Great Barrier Reef to climate change. Climate change and the Great Barrier Reef Great Barrier Reef Marine Park Authority and Australian Greenhouse Office, Australia, pp515-554

Furnas MJ (2003) Catchments and corals: Terrestrial runoff to the Great Barrier Reef. Australian Institute of Marine Science and CRC Reef, Townsville, Australia

Furnas MJ, Mitchell AW, Skuza M (1995) Nitrogen and phosphorus budgets for the Central Great Barrier Reef shelf. Great Barrier Reef Marine Park Authority, Research Publication No 36:pp 194

Hallock P (2000) Larger Foraminifers as indicators of coral reef vitality. In Martin, R (ed) Environmental micropaleontology. Plenum Press Topics in Geobiology 15:121-150

Hallock P, Lidz BH, Cockey-Burkhard EM, Donnelly KB (2003) Foraminifera as bioindicators in coral reef assessment and monitoring: the FORAM index. Environ Monit Assess 81:221238

Hallock P, Williams DE, Toler SK, Fisher EM, Talge HK (2006) Bleaching in reef-dwelling foraminifers: implications for reef decline. Proc 10th Int Coral Reef Symp: 729-737

Haunold TG, Baal C, Piller WE (1997) Benthic foraminiferal associations in the northern Bay of Safaga, Red Sea, Egypt. Mar Micropaleontol 29:185-210

Hoegh-Guldberg O, Mumby PJ, Hooten AJ, Steneck RS, Greenfield P, Gomez E, Harvell CD, Sale PF, Edwards AJ, Caldeira K (2007) Coral reefs under rapid climate change and ocean acidification. Science 318:1737

Hohenegger J (1994) Distribution of living larger Foraminifera NW of Sesoko- Jima, Okinawa, Japan. Mar Ecol 15:291-334

Hohenegger J, Yordanova E, Nakano Y, Tatzreiter F (1999) Habitats of larger Foraminifera on the upper slope of Sesoko Island, Okinawa, Japan. Mar Micropaleontol 36:109-168

Humphrey C, Weber M, Lott C, Cooper T, Fabricius K (2008) Effects of suspended sediments, dissolved inorganic nutrients and salinity on fertilisation and embryo development in the coral Acropora millepora (Ehrenberg, 1834). Coral Reefs 27:837-850

Jongman RHG, Ter Braak CJF, van Tongeren ORF (1995) Data analysis in community and landscape ecology. Cambridge University Press, Cambridge, p 299

Jorissen FJ (2002) Benthic foraminiferal microhabitats below the sediment-water interface. In: Sen Gupta BK (ed) Modern Foraminifera, 2nd edn. Kluwer Academic Publishers, Boston, pp 161-179

Keesing JK (1990) Feeding biology of the crown-of-thorns starfish, Acanthaster planci (Linnaeus). Ph. D. dissertation, James Cook University of North Queensland, Townsville, Australia, p197

Langer MR, Hottinger L (2000) Biogeography of selected "larger" Foraminifera. Micropaleontology 46:105-125

Lirman D, Fong P (2007) Is proximity to land-based sources of coral stressors an appropriate measure of risk to coral reefs? An example from the Florida Reef Tract. Mar Pollut Bull 54:779-791
Lobegeier MK (2002) Benthic Foraminifera of the family Calcarinidae from Green Island Reef, Great Barrier Reef Province. J Foraminifer Res 32:201-216

Marshall PA, Baird AH (2000) Bleaching of corals on the Great Barrier Reef: differential susceptibilities among taxa. Coral Reefs 19:155-163

Marshall P, Johnson J (2007) The Great Barrier Reef and climate change: vulnerability and management implications. In: Johnson JE, Marshall PA (eds) Climate change and the Great Barrier Reef. Great Barrier Reef Marine Park Authority and the Australian Greenhouse Office, Australia, pp 774-801

McCulloch M, Fallon S, Wyndham T, Hendy E, Lough J, Barnes D (2003) Coral record of increased sediment flux to the inner Great Barrier Reef since European settlement. Nature 421:727-730

Neil DT, Orpin AR, Ridd PV, Yu B (2002) Sediment yield and impacts from river catchments to the Great Barrier Reef lagoon. Mar Freshw Res 53:733-752

Nobes K, Uthicke S (2008) Benthic Foraminifera of the Great Barrier Reef: A guide to species potentially useful as Water Quality Indicators. Report to the Marine and Tropical Sciences Research Facility. Reef and Rainforest Research Centre Limited, Cairns, p44 available at: http://www.rrrcorgau/publications/downloads/ 371-AIMS-Nobes-etal-2008-Benthic-Foraminifera-of-the-GBRpdf

Nobes K, Uthicke S, Henderson R (2008) Is light the limiting factor for the distribution of benthic symbiont bearing Foraminifera on the Great Barrier Reef? J Exp Mar Biol Ecol 363:48-57

Pandolfi JM, Bradbury RH, Sala E, Hughes TP, Bjorndal KA, Cooke RG, McArdle D, McClenachan L, Newman MJH, Paredes G, Warner RR, Jackson JBC (2003) Global trajectories of the longterm decline of coral reef ecosystems. Science 301:955-958

Parsons TR, Maita Y, Lalli CM (1984) A manual of chemical and biological methods for seawater analysis. Pergamon Press, Oxford

Philipp E, Fabricius K (2003) Photophysiological stress in scleractinian corals in response to short-term sedimentation. J Exp Mar Biol Ecol 287:57-78

Pratchett MS (2007) Feeding preferences of Acanthaster planci (Echinodermata: Asteroidea) under controlled conditions of food availability. Pac Sci 61:113-120

Queensland Government and Commonwealth of Australia (2003) Reef water quality protection plan; for catchments adjacent to the Great Barrier Reef World Heritage Area. Queensland Department of Premier and Cabinet, Brisbane, p 43. http://www. environmentgovau/coasts/pollution/reef/

R Development Core Team (2006) R: A language and environment for statistical computing. R Foundation for Statistical Computing, Vienna, Austria

Renema W (2003) Larger Foraminifera on reefs around Bali (Indonesia). Zool Ver 345:337-366

Renema W (2006) Habitat variables determining the occurrence of large benthic Foraminifera in the Berau area (East Kalimantan, Indonesia). Coral Reefs 25:351-359

Renema W, Troelstra SR (2001) Larger Foraminifera distribution on a mesotrophic carbonate shelf in SW Sulawesi (Indonesia). Palaeogeogr Palaeoclimatol Palaeoecol 175:125-146

Schueth J, Frank T (2008) Reef Foraminifera as bioindicators of coral reef health: Low Isles Reef, Northern Great Barrier Reef, Australia. J Foraminifer Res 38:11-22

Stafford-Smith MG, Ormond RFG (1992) Sediment-rejection mechanisms of 42 species of Australian scleractinian corals. Aust J Mar Freshw Res 43:683-705

Sweatman H, Thompson A, Delean S, Davidson J, Neale S (2007) Status of near-shore reefs of the Great Barrier Reef 2004. Marine and Tropical Sciences Research Facility Research Report Series: Reef and Rainforest Research Centre Limited, Cairns, p169 
Tager T, Webster J, Potts D, Renema W, Braga J, Pandolfi J (in press) Community dynamics of Pleistocene coral reefs during alternative climatic regimes. Ecology

Titlyanov EA, Latypov YY (1991) Light-dependence in scleractinian distribution in the sublittoral zone of South China Sea Islands. Coral Reefs 10:133-138

Uthicke S (2006) Photosynthetic efficiency and rapid light curves of sediment-biofilms along a water quality gradient in the Great Barrier Reef, Australia. Mar Ecol Prog Ser 322:61-73

Uthicke S, Nobes K (2008) Benthic Foraminifera as indicators for terrestrial runnoff: A foram index for the GBR. Estuar Coast Shelf Sci 78:763-773

Valderrama JC (1981) The simultaneous analysis of total nitrogen and total phosphorus in natural waters. Mar Chem 10:109-122

van Woesik R, Tomascik T, Blake S (1999) Coral assemblages and physico-chemical characteristics of the Whitsunday Islands: evidence of recent community changes. Mar Freshw Res 50: $427-440$

Wakeford M, Done TJ, Johnson CR (2008) Decadal trends in a coral community and evidence of changed disturbance regime. Coral Reefs 27:1-13

Williams DE, Hallock P, Talge HK, Harney JN, McRae G (1997) Responses of Amphistegina gibbosa populations in the Florida Keys to a multi-year stress event (1991-96). J Foraminifer Res 27:264-269

Wooldridge S, Brodie J, Furnas M (2006) Exposure of inner-shelf reefs to nutrient enriched runoff entering the Great Barrier Reef Lagoon: Post-European changes and the design of water quality targets. Mar Pollut Bull 52:1467-1479

Yordanova EK, Hohenegger J (2002) Taphonomy of larger Foraminifera: relationships between living individuals and empty tests on flat reef slopes (Sesoko Island, Japan). Facies 46:169-204 